\title{
TINDAK PIDANA PENYEBARAN VIRUS PADA INTERNET DIHUBUNGKAN DENGAN UNDANG-UNDANG TEKNOLOGI INFORMASI
}

\author{
Oleh : Suisno, SH, M.Hum
}

\begin{abstract}
Abstrak
Salah satu kasus yang terjadi dalam dunia teknologi informasi adalah masuknya virus pada komputer melalui jaringan internet. pelaku atau cracker yang melakukan tindak pidana dalam bidang teknologi informasi tentang penghancuran dan pengrusakan yang dilakukan oleh virus yang terjadi di dunia maya.Dalam hal ini penulis mencoba untuk melakukan penlitian dengan mamasukan Hukum positif di Indonesia yang dapat menjerat tindak pidana penghancuran dan pengrusakan data dan program dihubungkan dengan Kitab Undang-undang Teknologi Informasi.

Penelitian yang dilakukan oleh penulis bersifat Deskriftif analisis yaitu suatu metode yang melukiskan fakta-fakta berupa data bahan hukum primer, sekunder dan tersier, sedangkan metode pendekatan menggunakan yuridis normatife yaitu suatu metode yang digunakan dimana permasalahan yang diteliti ada hubungannya dengan peraturan perundang-undangan. Adapun alat analisis yang digunakan penulis adalah menggunakan secara yudisis kualitatif yaitu perundangundangan yang satu tidak boleh bertentangan dengan perundang-undangan yang lain, memperhatikan hierarkies perundang-undangan dan memperhatikan kepastian hukum yaitu apakah perundang-undangan yang diteliti benar-benar dilaksankan atau tidak.

Berdasarkan hasil penelitian, dapat diketahui bahwa tindak pidana penghancuran dan pengrusakan data dan program melalui internet adalah suatu tindakan berupa perbuatan menghancurkan dan merusakan data dan program milik orang lain tanpa seijin pemilik data dan program,pasal 33 ayat 1 UU Teknologi Informasidapat digunakan untuk menghukum para pelaku berdasarkan arrest listrik yang menyatakan bahwa suatu benda meskipun tidak berwujud, apabila memiliki nilai ekonomis atau mempunyai nilai guna bagi pemiliknya, maka dapat dianggap sebagai benda dan dapat dijadikan objek dari suatu tindak pidana. Selain itu terdapat peraturan lain yang dapat digunakan oleh hakim yaitu Undang-undang Teknologi Informasi yang dapat digunakan oleh hakim dengan penafsiran futuristik atau antisipasif.Dengan demikian upaya hukum yang dilakukan oleh pemilik data dan program komputer secara pidana dapat menggunkan pasal 33 ayat 1 UU Teknologi Informasi tentang penghancuran dan pengrusakan barang.
\end{abstract}

\section{Kata kunci : Tindak Pidana, Virus, Undang-undang Teknologi Informasi}

\section{Pendahuluan}

Perkembangan komputer dewasa ini seiring dengan perubahan zaman, hal yang terjadi pada masyarakat dunia yang selalu ingin mencari sesuatu yang baru dengan mengolah, meneliti dan mengembangkan serta membuat hasil pemikirannya sebagai penemuan baru yang canggih dan modern.Hal ini sudah menjadi pola pikir masyarakat dunia untuk mengembangankan teknologi sebagaiacuanuntuk bersaing menemukan sesuatu yang baru dalam bidang teknologiTeknologi yang sedang berkembang sekarang ini salah satunya adalah dengan dikenalnya media elektronik yang memiliki kemampuan yang sangat besar dan menembus batas teritorial suatu negara. Dalam mengolah datanya media elektronik yang mendukungnya yaitu media komputer.Didalam perangkat komputer atau software terdapat program-program canggih yang dapat memperoleh informasi secara cepat serta mengolahnya secara tepat dengan internet. Dalam hal ini internet merupakan salah satu produk gabungan teknologi antara 
teknologi komputer dengan telekomunikasi lain yang sempurna.

Perkembangan teknologi yang semakin pesat, rupanya diikutipula dengan perkembangan kejahatan yang berbasis teknologi canggih. Salah satu contohnya adalah serangan virus terhadap komputer. Pada awalnyaVirus diciptakan oleh seorang ahli komputer dengan tujuan yang pada umumnya adalah untuk merusak dan menyengsarakan pengguna komputer di dunia . Virus-virus komputer merupakan penyakit umum dalam dunia teknologi komputer. Salah satunya adalah virus. Dalam hal ini virus tersebut dapat menyebar dengan cepat melalui jaringan komputer yang terbuka seperti internet.

Virus adalah sebuah program dalam komputer. Seperti program komputer lainnya, didalamnya terdapat instruksi yang dapat melakukan tugas tertentu. Virus yang ganas dapat menyebabkan seluruh data pada Hardisk akan hilang bahkan virus dapat merusak Hardware komputer jika dalam komputer tersebut sudah terdapat virus sebelumnya.

Sebuah virus adalah sebuah program jahat yang disamarkan sebagai format lain seperti sebuah Scren Server atau data gambar. Cara kerja virus adalah jika pada saat dieksekusikan atau dipindahkan pada komputer maka sebuah virus dapat mengambil informasi dari sistem komputer, seperti nama user dan Passwordnya atau jika digunakan oleh seorang hacker atau cracker jahat dapat mengambil alih komputer secara remote atau dari jarak yang jauh. Hal ini tentu saja merugikan pengguna komputer, karena dapat menyebabkan data pada komputer menjadi hancur dan rusak, dan hal ini tidak lepas daritangan seorang ahli komputer yang dengan sengaja membuat virus untuk menghancurkan dan mengrusak program-program yang ada dalam komputer milik orang lain.

\section{Metode Penelitian}

Metode yang digunakan dalam penelitian ini adalah metode penelitian hukum dengan pendekatan yuridis normatif yaitu suatu metode dimana hukum dikonsepsikan sebagai norma, kaidah, atau suatu metode yang menitik beratkan penelitian terhadap data kepustakaan, atau yang disebut dengan data sekunder.Metode ini dipergunakan mengingat permasalahan yang diteliti adanya hubungan peraturan perundang-undangan yang satu dengan yang lainnya.

Oleh karena type penelitian yang digunakan adalah yuridis normatif, Maka pendekatan yang digunakan pendekatan perundangundangan. Pendekatan tersebut melakukan pengkajian pengaturan perundang-undangan yang berhubungan dengan pokok permasalahan.Pendekatan ini bermaksud menganalisa kejahatan dalam komputer,khususnya dalam pengrusakan dan penghancuran virus pada komputer.

\section{Hasil Dan Pembahasan}

Virus komputer merupakan
program komputer yang dapat menggandakan atau menyalin dirinya sendiri dan menyebar dengan cara menyisipkan salinan dirinya ke dalam program atau dokumen lain. Virus komputer dapat dianalogikan dengan virus biologis yang menyebar dengan cara menyisipkan dirinya sendiri ke sel makhluk hidup. Virus komputer dapat merusak (misalnya dengan merusak data pada dokumen), membuat pengguna komputer merasa terganggu, maupun tidak menimbulkan efek sama sekali.

Virus komputer umumnya dapat merusak perangkat lunak komputer dan tidak dapat secara langsung merusak perangkat keras komputer tetapi dapat mengakibatkan kerusakan dengan cara memuat program yang memaksa over process ke perangkat tertentu. Efek negatif virus komputer adalah memperbanyak 
dirinya sendiri, yang membuat sumber daya pada komputer (seperti penggunaan memori) menjadi berkurang secara signifikan.Hampir 95\% virus komputer berbasis sistem operasi Windows.Sisanya menyerang Linux/GNU, Mac, FreeBSD, OS/2 IBM, dan Sun Operating System. Virus yang ganas akan merusak perangkat keras.

Untuk mengaktifkan internet atau jaringan komputer, diperlukan orang atau manusia atau pelaku untuk mengoperasikannya.Manusia yang menggunakan internet dengan tujuan jahat yang membuat internet menjadi rusak, hancur dan berantarakan dinamakan hacker hitam/ cracker.Sedangkan hacker putih merupakan hacker yang masih memiliki motivasi untuk tujuan meningkatkan keamanan jaringna internet.

Hacker secara harfiah berarti mencincang atau membacok.Dalam arti luas adalah mereka yang menyusup atau melakukan perusakan melalui komputer.Hacker dapat didefinikan juga sebagai kemampuan yang dimiliki oleh seorang manusia yang dengan kemampuan yang dimilikinya melakukan kejahatan, baik pencurian nomor kredit, pengrusakan situs, atau pengrusakan situs milik orang lain. Hacker yang memiliki tujuan yang jahat selalu bertentangan dengan hacker topi putih.Hacker hitam kemudian menamakan dirinya dengan Cracker.

\section{Proses Penyebaran Virus Pada Komputer}

Dalam proses penyebaran virus, seorang Hacker atau cracker baik yang amatir ataupun yang sudah profesional memiliki langkah-langkah tertentu dalam melakukan akses pada suatu sistem komputer,yang secara sederhana dapat digambarkan sebagai berikut :

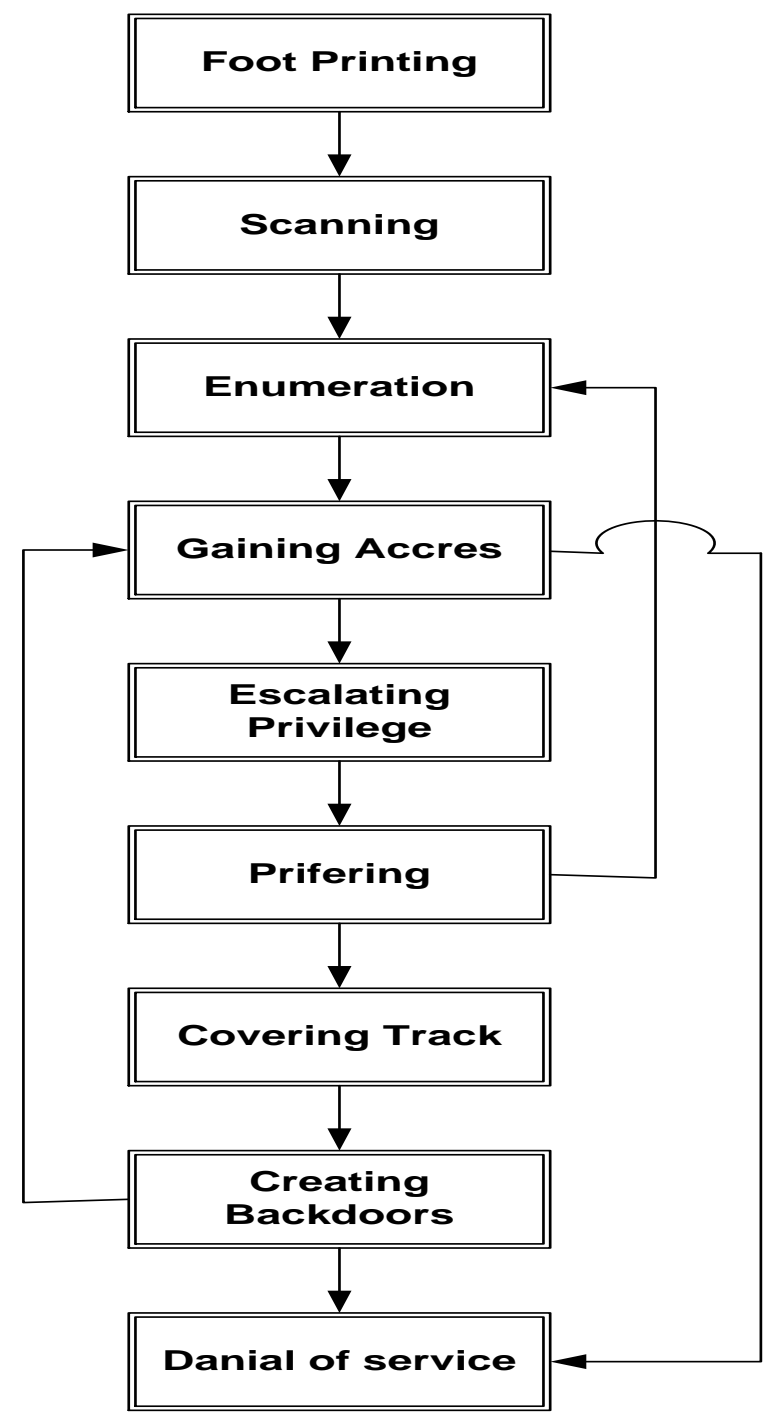

Untuk melalukan hacking, seorang hacker dapat menggunakan komputer sederhana atau minimal yang bisa dipakai untuk mengakses internet meskipun semakin baik atau tinggi kemampuan komputer yang dipakai akan semakin baik proses dan hasilnya. Proses menghacking pada suatu komputer memiliki langkah-langkah yang harus dilakukan oleh seorang hacker, langkah sederhana yang dapat dilakukan adalah sebagai berikut :

\section{Footprinting}

Mencari rincian informasi terhadap sistemsistem untuk dijadikan sasaran, mencakup 
pencarian informasi dengan search engine, whois, dan DNS zone transfer. Dalam Footprinting, hacker baru mencari-cari sistem mana yang dapat disusupi. Footprinting merupakan kegiatan pencarian data berupa:

-menentukan ruang lingkup (scope) aktivitas atau serangan

-mengintai jaringan

Semua kegiatan dapat dilakukan dengan tools dan informasi yang tersedia di bebas di internet. Kegiatan footprintig ini diibaratkan mencari informasi yang tersedia umum melalui buku telepon.Tools yang tersedia ini diataranya : Teleport Pro(, Whois for 95/9/NT, NSLookup, Traceroute 0.2

\section{Scanning}

Terhadap sasaran tertentu dicari pintu masuk yang paling mungkin,lebih bersifat aktif terhadap sistem-sistem sasaran. Disini diibaratkan hacker sudah mengetuk-ngetuk dinding sistem sasaran untuk mencari apakah ada kelemahannya.

\section{Enumeration}

Telaah intensif terhadap sasaran untuk mendapatkan mana yang proteksinya lebih lemah.Dalam hal ini sudah bersifat instrusif terhadap suatu sistem.Disini penyusup mencari account name yang absah, password yang ada.

\section{Gaining Access}

Mendapatkan data lebih banyak lagi untuk mulai mencoba mengakses sasaran.Meliputi mengintip dan merampas password, menebak password, serta melakukan buffer overflow.Gaining access adalah mencoba mendapatkan akses ke dalam suatu sistem sebagai user biasa.Ini merupakan kelanjutan dari kegiatan enumerasi, sehingga biasanya disini penyerang sudah mempunyai paling tidak user account yang absah, dan tinggal mencari passwordnya saja.

\section{Escalating Privilege}

Pada tahap ini, apabila baru mendapatkan user password ditahap sebelumnya, ditahap ini diusahakan mendapatkan privilese admin jaringan dengan password cracking.Dalam hal ini, penyerang sudah mendapatkan logon access pada sistem sebagai user biasa.

\section{Pilfering}

Dalam tahap ini, proses pengumpulan informasi dimulai lagi untuk mengidetifikasi mekanisme untuk mendapatkan akses ke trusted system. Dalam hal ini penyerang sudah berada dan menguasai suatu sistem dan selanjutnya mencari informasi lanjutan.

\section{Covering Tracks}

Pada tahap ini, begitu kontrol penuh terhadap sistem diperoleh, maka pada tahap ini waktunya menutup jejak menjadi salah satu tugas yang harus dikerjakan oleh seorang hacker.

\section{Backdoor}

Pintu belakang diciptakan pada berbagai bagian dari sistem untuk memudahkan masuk kembali sistem ini dengan cara membentuk user account palsu, menanamkan servis pengendali jarak jauh serta monitoring tool, dan menggantikan aplikasi dengan Virus.

\section{Denial of Service}

Apabila semua usaha diatas gagal, penyerang dapat melumpuhkan sasaran sebagai usaha terakhir.

\section{Ruang Lingkup Cyber Law}

Pembahasan mengenai ruang lingkup "cyber law" dimaksudkan persoalan atau aspek-aspek hukum yang diperkirakan berkaitan dengan pemanfaatan Internet. Secara garis besar ruang lingkup "cyber law" ini berkaitan dengan persoalanpersoalan atau aspek hukum dari ECommerce, Trademark/Domain Names, Privacy and Secu rity on the Internet, 
Copyright, Defamation, Content Regulation, Disptle Settlement, dan sebagainya.

Berikut ini adalah ruang lingkup atau area yang harus dicover oleh cyberlaw. Ruang lingkup cyberlaw ini akan terus berkembang seiring den gan perkembangan yang terjadipada pemanfaatan Internet dikemudian hari.

1. Electronic Commerce.

Pada awalnya electronic commerce (E-Commerce) ber gerak dalam bidang retail seperti perdagangan $\mathrm{CD}$ atau buku lewat situs dalam World Wide Web (www). Tapi saat ini E-Commerce sudah melangkah jauh menjangkau aktivitas-aktivitas di bidang perbankan dan jasa asuransi yang meliputi antara lain "account inquiries", "loan transaction", dan sebagainya. Sampai saat ini belum ada pen gertian yang tunggal mengenai E-Commerce. Hal ini disebabkan karena hampir setiap saat muncul bentukbentuk baru dari E- Commerce dan tampaknya E-Commerce ini merupakan salah satu aktivitas cyberspace yang berkembang sangat pesat dan agresif. Sebagai pegangan (sementara) kita lihat definisi E-Commerce dari ECEG-Australia (Electronic Cornmerce Ex pert Group) sebagai berikut: "Electronic commerce is a broad concept that covers any commercial transaction that is effected via electronic means and would include such means as facsimile, telex, EDI, Internet and the telephone".

Secara singkat E-Commerce dapat dipahami sebagai transaksi perdagangan baik barang maupun jasa lewat media elektronik. Dalam operasionalnya ECommerce ini dapat berbentuk B to B (Business to Business) atau B to C (Business to Consumers). Khusus untuk yang terakhir (B to C), karena pada umumn ya posisi konsumen tidak sekuat perusahaan dan dapat menimbulkan beberapa persoalan yang menyebabkan para konsumen agak hati-hati dalam melakukan transaksi lewat Internet.

\section{Domain Name}

Domain name dalam Internet secara sederhana dapat diumpamakan seperti nomor telepon atau sebuah alamat. Contoh, domain name untuk Monash University Law School, Australia adalah "law.monash.edu.au". Domain name dibaca dari kanan ke kiri yang menunjukkan tingkat spesifikasinya, dari yang paling umum ke yang paling khusus. Untuk contoh di atas, "au" menunjuk kepada Australia sebagai geographical region, sedangkan "edu" artinya pendidikan (education) sebagai Toplevel Domain name (TLD) yang menjelaskan mengenai tujuan dari institusi tersebut. Elemen seIanjutnya adalah "monash" yang merupakan "the SecondLevel Domain name" (SLD) yan g dipilih oleh pendaftar domain name, sedangkan elemen yang terakhir "law" adalah "subdomain" dari monash Gabungan antara SLD dan TLD dengan berbagai pilihan subdomain disebut "domain name".

Domain names diberikan kepada organisasi, perusahaan atau individu oleh InterNIC (the Internet Network Information Centre) berdasark an kontrak dengan the National Science Foundation (Amerika) melalui Network Solutions, Inc. (NSI). Untuk mendaftarkankan sebuah domain name melalui NSI seseorang cukup membuka situs InterNIC dan mengisi sejumlah form InterNIC akan melayani para pendaftar berdasarkan prinsip "first come first served". InterNIC tidak akan memverifikasi mengenai 'hak' pendaftar untuk memilih satu nama tertentu, tapi pendaftar harus menyetujui ketentuan-ketentuan yang tercantum dalam "NSI's domain name dispute resolution policy". Berdasarkan ketentuan tersebut, NSI akan menangguhkan pemakaian sebuah domain name yang diklaim oleh salah satu pihak sebagai telah memakai merk dagang yang sudah terkenal. Keturutsertaan Pelaku Tindak Pidana
yang Diatur Dalam Pasal 55 dan 56 Kitab
Undang-Undang Hukum Pidana 
Keturutsertaan atau deelneming oleh pembuat undang-undang diatur dalam pasal 55 dan pasal 56 Kitab Undang-undang Hukum Pidana. Ketentuan pidana pasal 55 KUHP berbunyi:

(1) Dihukum sebagai pelaku-pelaku dari suatu tindak pidana yaitu:

1.Mereka yang melakukan, menyuruh melakukan atau turut melakukan;

2.Mereka yang dengan pemberianpemberian, janji-janji, dengan menyalahgunakan kekuasaan atau keterpandangan, dengan kekerasan, ancaman atau dengan menimbulkan kesalahpahaman atau dengan memberikan kesempatan, sarana-sarana atau keterangan-keterangan, dengan sengaja telah menggerakan orang lain untuk melakukan tindak pidana yang bersangkutan.

(2) Mengenai mereka yang disebutkan terakhir ini, yang dapat dipertanggungjawabkan kepada mereka itu hanyalah tindakan-tindakan yang dengan sengaja telah mereka gerakan untuk dilakukan oleh orang lai, berikut akibatakibatnya.

Bentuk-bentuk delneming atau keturutsertaan yang ada menurut ketentuan pidana pasal 55 dan 56 KUHP adalah :

1. doen plegen atau menyuruh melakukan atau yang didalam doktrin juga sering disebut sebagai middellijk daderschap;

2. medeplegen atau turut melakukan ataupun yang didalam doktrin disebut sebagai mededaderschap;

3. uitloking atau menggerakan orang lain.

Menurut Prof. van Bemmelen pengertian dader adalah sebagai barikut (dalam bahasa Indonesia) :

"Pelaku itu adalah orang yang telah memenuhi unsur-unsur dari suatu delik, atau orang yang telah memenuhi semua syarat yang telah ditentukan didalam suatu rumusan delik"

Sedangkan menurut Hazewinkel-Suringa pengertian pelaku adalah sebagai berikut (dalam Bahasa Indonesia) : "yang dimaksud dengan pleger itu adalah setiap orang yang dengan seorang diri telah memenuhi semua unsur dari delik seperti yang telah ditentukan didalam rumusan delik yang bersangkutan. Juga tanpa adanya ketentuan pidana yang mengatur masalah deelneming itu, orang-orang tersebut dapat dihukum"

Didalam aturan hukum pidana, medeplegen merupakan suatu dadershap. Apabila seseorang itu melakukan suatu tindak pidana, maka biasanya ia disebut sebagai seorang dader atau seorang pelaku. Apabila beberapa orang secara bersama-sama melakukan suatu tindak pidana, maka setiap peserta didalam tindak pidana itu dipandang sebagai seorang mededader dari peserta atau peserta-peserta yang lain . Bentuk-betuk daderschap yang disebutkan dalam pasal 55 Kitab Undang-undang Hukum Pidana harus ditafsirkan sedemikian rupa, sehingga bentubentuk daderschap harus disamakan plegen (mejalani atau yang menjalankan).

Medeplegen menurut arrset HOGE RAAD tanggal 9 Februari 1914, N.J. 1914 halaman 648, W. 9620dan tanggal 9 Juni 1925, N.J 1925 halaman 785, W.11437 telah memberikan putusannya yang berbunyi sebagai berikut :

“ untuk adanya suatu medeplegen itu disyaratkan bahwa setiap pelaku itu mempunyai maksud yang diperlukan serta pengetahun yang disyaratkan untuk dapat menyatakan bersalah turut melakukan itu haruslah diselediki dan dibuktikan bahwa pengetahuan dan maksud tersebut memang terdapat pada tiap peserta"

Peneliti mengambil Pasal 55 jo 56 Kitab Undang-undang Hukum Pidana ini, karena keturut sertaan pelaku harus mendapatkan hukuman yang setimpal dengan perbuatannya dan karena Kitab Undang-undang Hukum Pidana merupakan ius constitutum, yaitu peraturan atau undang-undang yang berlaku pada saat ini (waktu tertentu dan tempat tertentu) yaitu sebagai hukum positif yang mengatur tindak pidana di Indonesia. 
Tindak Pidana Penyebaran Virus Pada Komputer Dihubungkan Dengan Tindak Pidana Penghancuran dan Pengrusakan Barang Pada Kitab Undang-Undang Teknologi Informasi

Proses menyebarnya virus pada komputer, tidak mungkin berlangsung dengan sendirinya, tetapi harus ada orang atau manusia yang mengoperasikan, mengaktifkan, dan mengendalikannya baik secara remote ataupun tidak. Sistem pengopersian, pengaktifan atau pengendalian ini dapat dilakukan oleh dader atau yang dikenal dengan sebutan cracker maupun oleh orang lain yang turut serta melakukan yang dikenal dengan sebutan mededader. Dengan demikian mededaderdapat diberi sanksi pidana apabila unsur-unsurnya dalam pasal 55 ayat (1) terpenuhi yaitu :

"Orang yang turut melakukan dalam arti kata bersama-sama melakukan, sedikitdikitnya harus ada dua orang yaitu orang yang melakukan (dader), dan orang yang turut melakukan (mededader) peristiwa pidana itu.Disini diminta bahwa, kedua orang itu semuanya melakukan perbuatan pelaksanaan".

Apabila seseorangtidak mengetahui dan tidak terbukti adanya unsur kesengajaan untuk mengirimkan virus pada data dan program komputer milik orang lain maka ia harus dinyatakan tidak terbukti bersalah oleh hakim, namun apabila seseorang mengetahui dan menyadari bahwa dalam proses pengiriman data dan programnya itu terdapat virus dan telah mengetahui akibat yang akan terjadi atau akibat yang akan ditimbulkan dengan melakukan tindakan tersebut maka pelaku tersebut dapat dijerat dengan pasal tersebut.

Hakim juga dapat membuat pertimbangan hukum dalam memberikan putusan pada kasus seperti ini antara lain denganmempertimbangkan pasal 33 ayat 1 UU Teknologi Informasi yang berbunyi sebagai berikut:
"Barang siapa dengan sengaja dan melawan hukum mengubah, menghapus, atau merusak data komputer atau program komputer, atau data elektronik lainnya dipidana dengan pidana penjara paling lama 1 ( satu) tahun dan/atau denda paling banyak Rp. 100.000.000,00 (seratus juta rupiah)"

Pertimbangan yang didasarkan pada pasal 33 ayat 1 Undang-Undang (UU) tersebut adalah ketentuan pasal 28 ayat (1) Undang-Undang Nomor 4 Tahun 2004 tentang kekuasaan kehakiman, bahwa hakim wajib untuk menemukan dan menggali nilainilai yang hidup didalam masyarakat.

\section{Kesimpulan Dan Saran}

\section{A. Kesimpulan}

Berdasarkan pembahasan yang telah penulis kemukakan pada bab sebelumnya, maka diperoleh kesimpulan sebagai berikut:

1. Hukum positif di Indonesia dapat menjerat pelaku tindak pidana computer khususnya tentang penghancuran dan pengrusakan compute rmelalui serangan virus pada internet, dapat dijerat dengan Kitab Undang-Undang Hukum Pidana tentang penghancuran dan pengrusakan barang. Barang atau benda seperti data dan program dalam computer dapat diartikan sebagai benda tidak berwujud yang terdapat dalam media elektronik yang memiliki kekuatan hukumun tuk dilindung iseperti yang diungkapkan dalam UNCITRAL Model Law on Electronic Commerce yang menyebutkan bahwa segala bentuk informasi (data gambar yang disusupi oleh virus) yang menggunakan media elektronik memiliki aklibat hukum atau kekuatan hukum. Selain itu dengan menggunakan penafsiran futuristic atauan tisifasif yaitu suatu penafsiran yang dilakukan terhadap peraturan perundang-undangan yang belum mempunyai kekuatanhokum tetap dapat dijadikan dasar pertimbangan hakim untuk memberi putusan terhadap pelaku tindak pidana penghancuran dan pengrusakan data dan program pada komputer. Upaya lain untuk mengisi kekosongan hukum dapat 
dilakukan dengan adanya dasar hokum pasal 28 ayat (1) tentang Kekuasaan Kehakiman yang menyebutkan bahwa hakim wajib menggali, mengikuti, dan memahami nilainilai hukumdan rasa keadilan yang hidup dalam masyarakat. Dengan demikian hakim tidak boleh menolak setiap tindak pidana baru yang dihadapkan kepadanya meskipun belum adanya peraturan baru yang dapat diterapkan untuk menjerat pelaku dalam tindak pidana tersebut.

2. Pelakutindak pidanaatau Cracker dalam tindakan melakukan penyebaran virus pada komputer yang memiliki fungsi menghancurkan dan merusakan data atau program pada computer dapat dijerat dengan tindak pidana pada KitabUndangUndangHukumPidana. Tindakpidana penghancuran dan pengrusakan data dan program yang dilakukanoleh virus dilakukan didunia maya atau dalam arti lain dilakukan pada suatu benda yang tidak berwujud. Dengan melihat kepada arrest HOGE RAAD tanggal 23 mei 1921 tentang electriciteisarrest atau arrest listrik dimana penegak hukump ada saat itu (menurut arrest HOGE RAAD) telah melakukan pembaharuan dalam mendefinisikan benda tidak berwujud ke dalam benda berwujud, maka dengan demikian hal ini dapat juga dilakukan kepada tindak pidana penghancuran dan pengrusakan barang dengan tidak menghilangkan unsur-unsur yang melekat pada Kitab Undang-undang Hukum pidana tersebut. Dengan demikian kekosongan hukum di Indonesia tidak terjadi sebelumadanya peraturan khusus yang menangani tindak pidana tentang perkembangan teknologi informasi khususnya dalam halpenyebaran virus pada computer melalui jaringan internet yang menyebabkan hancurnya atau rusaknya data atau program pada komputer.

\section{B. Saran}

1. Dengan adanya tindak pidana dalam dunia Teknologi Informasi tersebut maka pembuat Undang-undang diharuskan membuat dan menerapkan system perundang-undangan untuk mengatur hal tersebut, agar penegakan hukum di Indonesia dapat ditegakkan dan keadilan dapat dirasakan oleh masyarakat umum sebagai pengguna komputer.

2. Berdasarkan pasal 28 ayat 1 UndangUndang pokok kekuasaan kehakiman, seorang hakim tidakboleh menolak setiap kasus yang dihadapkan kepadanya. Hukum positif di Indonesia masih dapat digunakan sebelum terbentuknya hokum baru di Indonesia.

\section{DAFTAR PUSTAKA}

Edmon Makarim, Kompilasi Hukum Telematika, Cet. I, Jakarta,; Raja Grafindo

Persada, 2003.

P. A. F. Lamintang, Dasar Dasar Hukum Pidana Indonesia, Cet. III, Bandung; Citra Aditya Bakti, 1997.

Agus Raharjo, Cybercrime, Pemahaman Dan Upaya Pencegahan Kejahatan Berteknologi, Cet. I, Bandung; Citra Aditya Bakti, 2002

Budi Agus Riswandi, Hukum Internet Di Indonesia, Cet. I, Yogyalarta, UII Pers, 2003.

Riduan Syahrani, Seluk Beluk Dan Asas-Asas Hukum Perdata, Cet.4, Bandung, Alumni, 2000.

C.S.T. Kansil, Pengantar Ilmu Hukum Dan Tata Hukum Indonesia, Cet. 8, Jakarta, Balai Pustaka, 1989.

Utrecht. E. Drs, Pengantar Dalam Hukum Indonesia, Cet. 3. Jakarta, N.V Penerbitan dan Balai Buku Indonesia, 1956

Apeldorn. L.J.Dr Pengantar Ilmu Hukum, Cet. I3, Jakarta, Jakarta, Pradnya Paramita, 1975.

Lamintang. P.A.F, Delik-Delik Khusus Kejahatan-Kejahatan Terhadap Harta Kekayaan, Cet. I, Bandung, Sinar Baru, 1989.

R. Soeroso, Pengantar Ilmu Hukum, Cet. 3, Jakarta, Sinar Grafika Offset, 2000 
S. Wojowasito, Kamus Umum Belanda Indonesia, Jakarta, Ichtiar Baru Van Hoeve, 2000

Muhamad Ali, Kamus Lengkap Bahasa Indonesia Modern, Jakarta, Amani Jakarta.

Edwin, Kamus Lengkap Inggris Indonesia Indonesia Inggris,Surabaya, Alumni.

Komisi Pemilihan Umum, Grand Design Sistem Informasi, Buku V, Keamanan (security), 2002

Mas Wigrantoro, Mirna Dian Avanti Siregar, Rancangan Undang-Undang Tindak Pidana Di Bidang Teknologi Informasi, Global Internet Pilicy Initiative Indonesia Berkerjasama dengan Indonesia Media Law And Policy Center, 2003.

Undang Tentang Teknologi Infomasi, Draft Ketiga.

Kitab Undang-Undang Hukum Pidana

$$
\text { Undang-Undang Republik }
$$

Indonesia Nomor 36 Tahun 1999 Tentang Telekomunikasi

Undang-undang Pokok Kekuasaan Kehakiman Nomor 4 Tahun 2004

Article, www.google.com

www.Yahoo.com

Article,

http://id.wikipedia.org/wiki/Virus_ komputer 07 Juli 2014

http://id.wikipedia.org/wiki/Hukum _siber 07 Juli 2014. 